\title{
Maytenus macrocarpa (Ruiz \& Pav.) Briq.: Phytochemistry and Pharmacological Activity
}

\author{
Milan Malaník ${ }^{1}{ }^{1}$, Jakub Treml ${ }^{2}$, Veronika Rjašková ${ }^{1}$, Karolina Tížková $^{1}$, Petra Kaucká $^{1}$, \\ Ladislav Kokoška ${ }^{3}$, Peter Kubatka ${ }^{4}$ and Karel Šmejkal ${ }^{1, *(1)}$
}

1 Department of Natural Drugs, Faculty of Pharmacy, University of Veterinary and Pharmaceutical Sciences Brno, Palackého tř. 1, 61242 Brno, Czech Republic; milan.malanik@seznam.cz (M.M.);

v.rjaskova@gmail.com (V.R.); karolina.kalvarova@gmail.com (K.T.); petra.kaucka9@gmail.com (P.K.)

2 Department of Molecular Biology and Pharmaceutical Biotechnology, Faculty of Pharmacy, University of Veterinary and Pharmaceutical Sciences Brno, Palackého tř. 1, 61242 Brno, Czech Republic; tremlj@vfu.cz

3 Department of Crop Sciences and Agroforestry, Faculty of Tropical AgriSciences, Czech University of Life Sciences Prague, Kamýcká 129, 16500 Praha-Suchdol, Czech Republic; kokoska@ftz.czu.cz

4 Department of Medical Biology, Jessenius Faculty of Medicine, Comenius University in Bratislava, 03601 Martin, Slovakia; Peter.Kubatka@jfmed.uniba.sk

* Correspondence: karel.mejkal@post.cz

Received: 31 May 2019; Accepted: 18 June 2019; Published: 20 June 2019

\begin{abstract}
Maytenus macrocarpa (Celastraceae) is a tree native to Amazonia. Its roots, leaves, bark, and combinations of these are used in traditional medicine mainly to treat rheumatism and, to a lesser extent, to heal wounds and to combat bronchitis and diarrhea. To date, mainly triterpenes and dihydro- $\beta$-agarofuran sesquiterpenes were isolated from $M$. macrocarpa. Extracts and selected pure compounds isolated from the leaves, roots, and stem bark showed antibacterial, antiviral, antiparasitic, anti-inflammatory, and cytotoxic activities in vitro. The aim of this review is to summarize the available ethnobotanical, phytochemical, and pharmacological information about this traditional Amazonian medicinal tree, as well as to attract the attention of phytochemists and pharmacognosists to this potentially interesting source of ethnopharmaceuticals.
\end{abstract}

Keywords: dihydro- $\beta$-agarofuran sesquiterpene; folk medicine; Maytenus macrocarpa; rheumatism; triterpene

\section{Introduction}

Maytenus macrocarpa (Ruiz \& Pav.) Briq. is a tree, up to $30 \mathrm{~m}$ tall, belonging to the family Celastraceae. Four hundred different species of the genus Maytenus Molina were identified [1]. Although M. macrocarpa is the most widely accepted scientific name, Celastrus macrocarpus Ruiz \& Pav., Haenkea macrocarpa (Ruiz \& Pav.) Steud., Haenkea multiflora Ruiz \& Pav., M. multiflora (Ruiz \& Pav.) Loes., and M. tarapotensis Briq. also refer to the same species. It is important to bear in mind that "chuchuhuasha" is a vernacular name for M. macrocarpa [2] even though M. chuchuhuasha actually refers to another species-M. krukovii A.C. Sm. Another used vernacular name, chuchuhuasi, may refer to one or both of the species M. macrocarpa and M. amazonica Mart. ex Reissek [3]. Other vernacular names in use are chuchuasi, chuchuasha [4], chuchuwasha, chuchuwasha blanca [5], chuchuhuasca [2], and chichtá or xixuá [6].

The fully correct classification of this plant is even more complicated because M. macrocarpa is often misidentified as M. ebenifolia Reissek or M. krukovii A.C. Sm. [1,7]. This chaos raised voices calling for reorganization of this plant family [8]. Recently, the genus Maytenus was split into two genera, resurrected Tricerma and maintained Plenckia and Fraunhofera as separate ones. Maytenus species in the 
tropical lineage were transferred to Monteverdia [9]; therefore, Monteverdia macrocarpa (Ruiz \& Pav.) Biral should currently be the scientific name in use instead of Maytenus macrocarpa.

A review touching the ethnopharmacology, phytochemistry, and pharmacology of some Maytenus species was published [10], but it made no specific reference to $M$. macrocarpa. The database literature search was performed in SciFinder and Google Scholar using keywords "Maytenus macrocarpa", its isolated compounds, and corresponding pharmacological activities.

\section{Geographical Distribution}

The M. macrocarpa tree grows exclusively in Amazonia. It is distributed in Bolivia, in Brazil in the state of Acre, in Columbia, in Ecuador in the provinces of Carchi, Esmeraldas, Imbabura, Napo, Pastaza, and Pichincha, in Peru in the regions Amazonas, Huánuco, Loreto, Madre de Dios, Paseo, San Martín, Tumbes, and Ucayali, and in Venezuela in the states of Anzoategui, Apure, Bolivar, and Miranda $[1,2,4,6]$. It grows mainly in lowland tropical rainforests, but exceptionally can be found up to $2000 \mathrm{~m}$ above sea level [1].

\section{Phytochemistry}

M. macrocarpa was used in tribal folk medicine for many years, and this aroused interest in the compounds it contains. We searched the available literature for phytochemical research carried out on substances presented in M. macrocarpa. As previously mentioned, the situation is complicated by the fact that several synonymous names are used for this plant, and the literature describing its phytochemical analysis is not very rich.

Mejia and Rengifo (1995) reported that M. macrocarpa contains some simple phenols and quinones, but this reference lacks exact descriptions of the structures identified [4]. The triterpenoids are a much better explored group of compounds isolated from M. macrocarpa. Several studies described the presence of mainly tetracyclic dammarane and pentacyclic friedelane triterpenes, and to a lesser extent quinonmethide, lupane, and oleane derived compounds. Another very interesting group of compounds obtained from $M$. macrocarpa consists of dihydro- $\beta$-agarofuran sesquiterpenes. Table 1 , including the corresponding references, presents a full list of the compounds isolated to date. Compounds presented in the Table 1 belong to various groups: dihydro- $\beta$-agarofuran sesquiterpenes (1-3), dammarane triterpenes (4-13), lupane triterpenes (14-18), and pentacyclic triterpenes (19-45). 
Table 1. Compounds isolated from Maytenus macrocarpa.

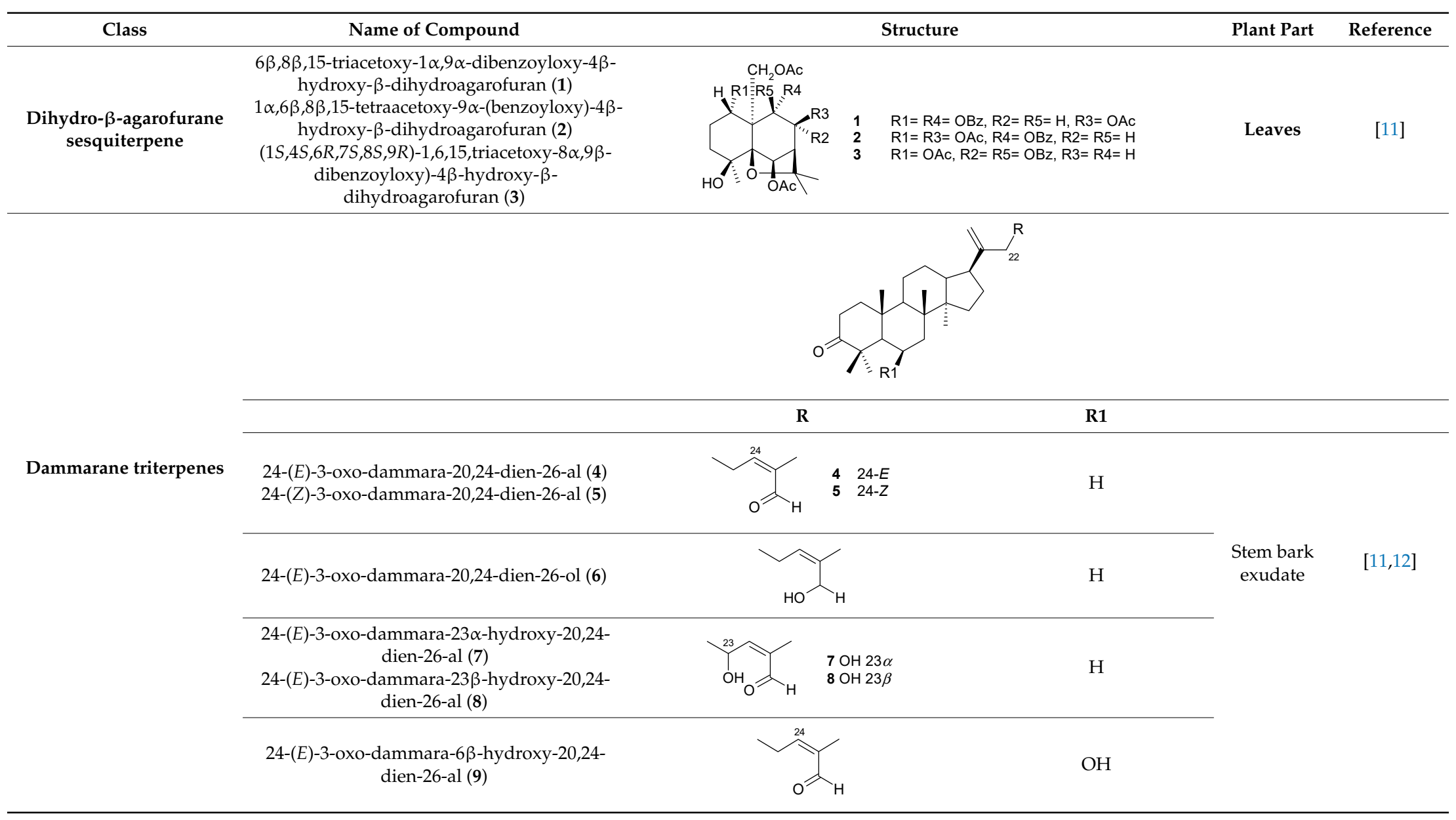


Table 1. Cont.

\begin{tabular}{|c|c|c|c|c|c|c|}
\hline Class & Name of Compound & Structure & & & Plant Part & Reference \\
\hline & $\begin{array}{l}\text { 24-(E)-3-oxo-dammara-6 } 6 \text {-hydroxy-20,24- } \\
\text { dien-26-ol (10) }\end{array}$ & \multicolumn{3}{|c|}{$\mathrm{OH}$} & & \\
\hline & $\begin{array}{c}\text { 23-(Z)-3,25-dioxo-25-nor-dammara-20,24-dien } \\
\text { (11) }\end{array}$ & \multicolumn{3}{|c|}{$\mathrm{H}$} & & \\
\hline & $\begin{array}{l}\text { 24-(E)-3-oxo-22-hydroxy-23-methylene- } \\
\text { dammara-20,24-dien-26-oic acid (12) }\end{array}$ & & \multicolumn{2}{|c|}{$\mathrm{H}$} & & \\
\hline \multirow{8}{*}{ Lupane triterpenes } & $\begin{array}{l}\text { 24-(Z)-3-oxo-dammara-20(21),24-dien-27-oic } \\
\text { acid (13) }\end{array}$ & & \multicolumn{2}{|c|}{$\mathrm{H}$} & & \\
\hline & & & & & & \\
\hline & & $\mathbf{R}$ & R1 & R2 & \multirow{6}{*}{ Bark } & \\
\hline & 3-(E)-caffeoylbetulin (14) & 3-(E)-caffeoyl & $\mathrm{H}$ & $\mathrm{OH}$ & & \multirow{4}{*}{ [13] } \\
\hline & 3-(Z)-p-coumaroylbetulin (15) & 3-(Z)-p-coumaroyl & $\mathrm{H}$ & $\mathrm{OH}$ & & \\
\hline & 3-(E)-p-coumaroylbetulin (16) & 3-(E)-p-coumaroyl & $\mathrm{H}$ & $\mathrm{OH}$ & & \\
\hline & nepeticin (17) & $\mathrm{OH}$ & $\mathrm{OH}$ & $\mathrm{H}$ & & \\
\hline & lupeol (18) & $\mathrm{OH}$ & $\mathrm{H}$ & $\mathrm{H}$ & & [11] \\
\hline
\end{tabular}


Table 1. Cont

\begin{tabular}{|c|c|c|c|c|c|c|c|}
\hline Class & Name of Compound & & Structure & & & Plant Part & Reference \\
\hline \multirow[t]{6}{*}{ Pentacyclic triterpenes } & & $\mathbf{R}$ & R1 & $\mathbf{R} 2$ & R3 & & \\
\hline & friedelin (19) & $\mathrm{CH}_{3}$ & $\mathrm{CH}_{3}$ & $\mathrm{H}$ & $\mathrm{CH}_{3}$ & $\begin{array}{c}\text { Stem bark } \\
\text { exudate, } \\
\text { leaves }\end{array}$ & {$[12,14-16]$} \\
\hline & canophyllol (20) & $\mathrm{CH}_{2} \mathrm{OH}$ & $\mathrm{CH}_{3}$ & $\mathrm{H}$ & $\mathrm{H}$ & \multirow{4}{*}{$\begin{array}{c}\text { Stem bark } \\
\text { exudate }\end{array}$} & {$[16,17]$} \\
\hline & 3-oxofriedelan-25-al (21) & $\mathrm{CH}_{3}$ & $\mathrm{CHO}$ & $\mathrm{H}$ & $\mathrm{H}$ & & {$[12,16,17]$} \\
\hline & 28-hydroxyfriedelane-1,3-dione (22) & $\mathrm{CH}_{2} \mathrm{OH}$ & $\mathrm{CH}_{3}$ & $=\mathrm{O}$ & $\mathrm{H}$ & & {$[12,16]$} \\
\hline & 3-oxo-29-hydroxyfriedelane (23) & $\mathrm{CH}_{3}$ & $\mathrm{CH}_{3}$ & $\mathrm{H}$ & $\mathrm{CH}_{2} \mathrm{OH}$ & & {$[12,14-16]$} \\
\hline \multicolumn{8}{|l|}{ Pentacyclic triterpenes } \\
\hline & & $\mathbf{R}$ & R1 & $\mathbf{R 2}$ & R3 & & \\
\hline & scutione (24) & $\mathrm{H}$ & $=\mathrm{O}$ & $\mathrm{H}$ & $\mathrm{CH}_{3}$ & \multirow{2}{*}{$\begin{array}{c}\text { Stem bark } \\
\text { exudate }\end{array}$} & {$[15,18]$} \\
\hline & netzahualcoyene (syn. vitideasin) (25) & $\mathrm{H}$ & $\mathrm{H}$ & $\mathrm{COOCH}_{3}$ & $\mathrm{CH}_{3}$ & & {$[12,15]$} \\
\hline
\end{tabular}


Table 1. Cont.

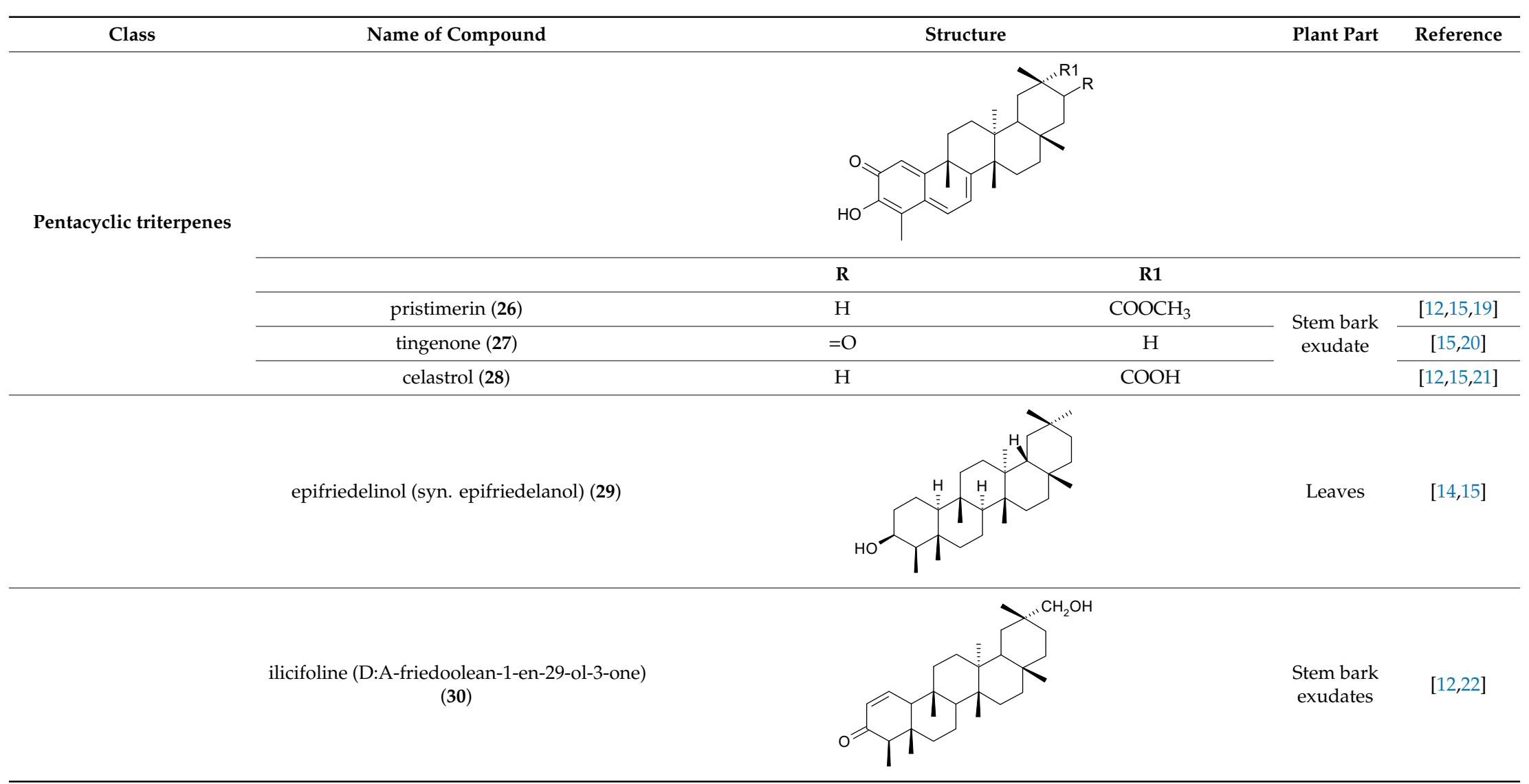


Table 1. Cont

\begin{tabular}{|c|c|c|c|c|}
\hline Class & Name of Compound & Structure & Plant Part & Reference \\
\hline & $\begin{array}{c}\text { According to Torpocco (2007), it was isolated } \\
\text { as olean-12-ene-3 } 3,6 \beta \text {-diol. Considering } \\
\text { given references, it was isolated as } \\
\text { olean-12-ene-3 } 3,16 \beta \text {-diol (syn. maniladiol, } \\
\text { daturadiol) (31) }\end{array}$ & & $\begin{array}{l}\text { Stem bark } \\
\text { exudates }\end{array}$ & {$[12,23]$} \\
\hline & macrocarpine A (32) & & Root & [24] \\
\hline & $\begin{array}{l}\text { macrocarpine B (33) } \\
\text { macrocarpine C (34) }\end{array}$ & & Root & [24] \\
\hline & macrocarpine D (35) & & Root & [24] \\
\hline
\end{tabular}


Table 1. Cont.

\begin{tabular}{|c|c|c|c|c|c|c|c|}
\hline \multirow[t]{8}{*}{ Class } & Name of Compound & & Stru & & & Plant Part & Reference \\
\hline & & R1 & R2 & R3 & R4 & & \\
\hline & $\begin{array}{c}\text { macrocarpoic acid A } \\
(3 \beta, 22 \alpha \text {-dihydroxy-olean-12-en-30-oic acid) } \\
(36)\end{array}$ & $\beta-\mathrm{OH}$ & $\mathrm{CH}_{3}$ & $\mathrm{COOH}$ & $\alpha-\mathrm{OH}$ & $\begin{array}{c}\text { Stem bark } \\
\text { exudates }\end{array}$ & [13] \\
\hline & $\begin{array}{c}\text { macrocarpoic acid B } \\
\text { (22 } \alpha \text {-hydroxy-olean-12-en-3-oxo-30-oic acid) } \\
(37)\end{array}$ & $=\mathrm{O}$ & $\mathrm{CH}_{3}$ & $\mathrm{COOH}$ & $\alpha-\mathrm{OH}$ & $\begin{array}{l}\text { Stem bark } \\
\text { exudates }\end{array}$ & [13] \\
\hline & $\begin{array}{l}\text { maytenfolic acid (triptotriterpenic acid A, } \\
3 \beta, 20 \alpha, 22 \alpha \text {-dihydroxy-olean-12-en-29-oic } \\
\text { acid) (38) }\end{array}$ & $\beta-\mathrm{OH}$ & $\mathrm{COOH}$ & $\mathrm{CH}_{3}$ & $\alpha-\mathrm{OH}$ & $\begin{array}{l}\text { Stem bark } \\
\text { exudates }\end{array}$ & [13] \\
\hline & triptotriterpenonic acid A (39) & $=\mathrm{O}$ & $\mathrm{COOH}$ & $\mathrm{CH}_{3}$ & $\alpha-\mathrm{OH}$ & $\begin{array}{l}\text { Stem bark } \\
\text { exudates }\end{array}$ & [13] \\
\hline & $\begin{array}{c}\text { 22-epi-maytenfolic acid (triptotriterpenic acid } \\
\text { B, } 3 \beta, 22 \alpha \text {-dihydroxy-olean-12-en-29-oic acid) }\end{array}$ & $\beta-\mathrm{OH}$ & $\mathrm{COOH}$ & $\mathrm{CH}_{3}$ & $\beta-\mathrm{OH}$ & $\begin{array}{c}\text { Stem bark } \\
\text { exudates }\end{array}$ & [13] \\
\hline & 22-epi-triptotriterpenonic acid A (41) & $=\mathrm{O}$ & $\mathrm{COOH}$ & $\mathrm{CH}_{3}$ & $\beta-\mathrm{OH}$ & $\begin{array}{c}\text { Stem bark } \\
\text { exudates }\end{array}$ & [13] \\
\hline & orthosphenic acid (42) & & & & & $\begin{array}{c}\text { Stem bark } \\
\text { extract }\end{array}$ & [13] \\
\hline
\end{tabular}


Table 1. Cont.

\begin{tabular}{ccc}
\hline Class & Name of Compound & Structure \\
3-(E)-coumaroyluvaol (macrocarpol A) $(43)$ \\
$3-(E)$-caffeoyluvaol (44)
\end{tabular}




\section{Folk Medicine}

The M. macrocarpa plant is very popular in South American folk medicine. M. macrocarpa preparations are used to treat rheumatism almost everywhere in Amazonia. Other uses vary in the different regions. Ethnopharmacological studies showed that $M$. macrocarpa possesses aphrodisiac and anti-diarrheic effects and can also be used as a health and postpartum tonic and to enhance the healing of broken bones [5]. It has antimalarial [3,25] and antileishmanial effects [3]. Some local tribes use it to treat unspecified colds and women's ailments, to enhance wound healing [26], or to cure skin cancer [27].

The most common local formulations use the stem bark and root of M. macrocarpa either decocted or macerated in the local rum, which is prepared from sugar cane [5]. The following traditional recipes are presented here to illustrate the situation: for the treatment of rheumatism, macerate $250 \mathrm{~g}$ of dried shredded roots in alcohol and drink a glass on an empty stomach in the morning and evening regularly for a period of one month. The stem bark of $M$. macrocarpa can be used for the same purpose. For treatment of cold and bronchitis, boil $200 \mathrm{~g}$ of stem bark in $2 \mathrm{~L}$ of water for $1 \mathrm{~h}$, add $250 \mathrm{~mL}$ of local rum, and allow this to macerate for ten days. Then, swallow a spoonful of this remedy every morning for 15 days [4]. Another interesting use of $M$. macrocarpa is as a component remedy of a strict diet that is part of a ritual procedure called sama, used by locals in the Chazuta valley of Peru. The sama is a 2-8-week-long period of fasting during which plants with laxative and emetic effects are primarily consumed, supplemented with plants with other effects, e.g., anti-rheumatic effects [28].

\section{Pharmacological Activities}

\subsection{Antibacterial and Antifungal Activity}

The increasing resistance of bacteria to antibiotics that are currently in use is forcing scientists to seek new compounds with strong antimicrobial activity. It is difficult to make a meaningful comparison of the results obtained in different antibacterial tests because the extracts and panels of test organisms employed are not standardized and different growth media were used in the assays. Some general endpoint criteria for assigning the activities of compounds or extracts, e.g., the half maximal inhibitory concentration $\left(\mathrm{IC}_{50}\right)$ of the antibacterial effect below $100 \mu \mathrm{g} / \mathrm{mL}$ for test extracts and the $\mathrm{IC}_{50}$ below $25 \mu \mathrm{M}$ for pure compounds were adopted, but the close values obtained by testing the extracts are accepted more readily. Some scientific teams use assays that generate results expressed in minimal inhibitory concentration (MIC) or minimal bactericidal concentration (MBC), which can be tricky to compare. Furthermore, the minimal requirement for valid antibacterial assays is the use of at least one strain of Gram-positive and one strain of Gram-negative bacterium [29]. According to a study conducted by Kloucek et al., an ethanolic extract obtained from the root bark of M. macrocarpa showed activity against Bacillus cereus American Type Culture Collection (ATCC) 11778, Bacillus subtilis ATCC 6633, Staphylococcus epidermidis ATCC 12228, Streptococcus pyogenes ATCC 19615, Escherichia coli ATCC 25922 (all at the MIC $125 \mu \mathrm{g} / \mathrm{mL}$ ), and Enterococcus faecalis ATCC 29212, Staphylococcus aureus ATCC 25923, Bacteroides fragilis ATCC 25285, Pseudomonas aeruginosa ATCC 27853, and Candida albicans ATCC 10231 (all at the MIC of $250 \mu \mathrm{g} / \mathrm{mL}$ ), whereas an ethanolic extract of stem bark did not show any activity against the same panel of bacterial strains [30]. The differences between the results of the antibacterial activity testing of extracts prepared from roots and those from stem bark suggest that the spectrum of compounds present in root parts is different from the compounds present in aerial parts. The active extracts showed activity comparable to the antibiotic (ciprofloxacin) used as the standard control [31]. However, the bacterial suspensions at a density of $10^{7}$ colony-forming units (CFU)/mL used for the tests could cause false-negative results [29], as confirmed by the data obtained for some compounds isolated from or present in M. macrocarpa. Scutione (24) showed strong activity against 11 Gram-positive bacterial strains (MIC $0.1-2.0 \mu \mathrm{g} / \mathrm{mL}$ ), but no activity against eight Gram-negative bacterial strains (Gonzalez et al. 1996). In the same study, scutione (24) showed modest cytotoxic activity against HeLa, Hep-2, and Vero cell lines. It would, therefore, be worth testing scutione (24) 
against methicillin-resistant S. aureus (MRSA) and vancomycin-resistant Enterococci (VRE) because of the threat they pose to the human population.

The betuline derivative 3-(Z)-cis-coumaroylbetulin (15) showed relatively good activity against $P$. aeruginosa and S. aureus at a concentration of $0.1 \mathrm{mg} /$ disc, whereas its trans isomer (16) showed much less activity. The antimicrobial activity was evaluated by the paper disc-agar diffusion method, where each disc $(6 \mathrm{~mm})$ was aseptically impregnated with $10 \mu \mathrm{L}$ of the solution of the test compound [32]. Maytenfolic acid (38) was shown to be active against $S$. aureus (MIC $=12.5 \mu \mathrm{g} / \mathrm{mL}$ ) and P. aeruginosa (MIC $=12.5 \mu \mathrm{g} / \mathrm{mL}$ ) [33]. Neither 24-(Z)-3-oxo-dammara-20(21),24-dien-27-oic acid (13) nor octa-nor-13-hydroxydammara-1-en-3,17-dione (45) exhibited toxicity for any of the eight yeast strains tested using concentrations of at least $100 \mu \mathrm{g} / \mathrm{mL}$ [12]. Friedelin (19) was identified as an antimycobacterial compound against Mycobacterium madagascariense and M. indicus pranii [34], but it showed low antimycobacterial activity against $M$. tuberculosis [35] and, similarly to canophyllol (20) [36], little or no activity against several fungal and bacterial species [37-41]. The growth of several bacterial species was inhibited by friedelin (19) according to the work of Viswanathan et al. [42], Ragasa et al. [43], Jain et al. [44], and Singh and Dubey [45]; the good antibacterial activity of this compound against both Gram-positive and Gram-negative bacterial strains was described by Kuete et al. [46,47] and Sahiq Ali et al. [48]; its weak activity against $S$. aureus was observed in a study done by Chiozem et al. [49].

\subsection{Antiviral Activity}

Triterpenes, especially pentacyclic triterpenes and their derivatives, are known for their antiretroviral activity [50,51]. Betulinic acid and its derivatives were especially well explored for this effect [52]. Studies reported that pentacyclic triterpenes inhibit human immunodeficiency virus (HIV) reverse transcriptase [53]. Several pentacyclic triterpenes were isolated from $M$. macrocarpa. Piacente et al. [13] conducted an assay with a panel of 13 pentacyclic triterpenes isolated from a chloroform extract of the bark of M. macrocarpa: triptotriterpenonic acid A (39), 3-(E)-caffeoylbetulin (14), macrocarpoic acid A (36), macrocarpoic acid B (37), maytenfolic acid (38), macrocarpol A (43), 3-(E)-caffeoyluvaol (44), 3-(Z)-p-coumaroylbetulin (15), nepeticin (17), orthosphenic acid (42), 22-epi-maytenfolic acid (40), 22-epi-triptotriterpenonic acid A (41), and 3-(E)-p-coumaroylbetulin (16). These compounds were tested for anti-HIV activity in C8166 T cells infected with the HIV-1MN strain. The most effective compound was shown to be 22-epi-triptotriterpenonic acid A (41), which inhibited the interaction between the glycoprotein gp120 located on the HIV envelope and the cluster of differentiation 4 (CD4) receptor of $\mathrm{T}$ cells by $55 \%$ at the half maximal effective concentration $\left(\mathrm{EC}_{50}\right)=1 \mu \mathrm{g} / \mathrm{mL}$. The selectivity index (the ratio of the cytotoxicity value against the particular cell line used to test the observed antiviral effect) was found to be 35, which is sufficient to warrant further testing [13]. However, it is difficult to compare results obtained from this study with other studies reporting the antiviral activities of other triterpenes because different research groups used different viral strains and infected cells, and, in many cases, the data for positive controls were not published. Testing of further compounds showed that triptotriterpenonic acid A (39) is also active as an antiviral compound, but it is not selective enough when compared with substances currently used in clinics [13]. Furthermore, 22-epi-maytenfolic acid (40) inhibited HIV replication in $\mathrm{H} 9$ lymphocyte cells with an $\mathrm{EC}_{50}$ value of $5.65 \mu \mathrm{g} / \mathrm{mL}$ [54]. Investigation of lupane derivatives revealed nepeticin (17) as a moderate inhibitor of HIV-1 replication in MT-2 cells infected with an X4 tropic HIV (NL4.3-Ren) $\left(\mathrm{IC}_{50}=10.4 \mu \mathrm{M}\right)$, whereas 3-(E)-caffeoylbetulin (14) and lupeol (18) were inactive [55].

The anti-HIV replication activities in H9 lymphocyte cells of friedelin (19) and canophyllol (20) were shown to be greater than $10 \mu \mathrm{g} / \mathrm{mL}$ [56]. However, friedelin (19) was found to have no activity when tested against hepatitis virus type C [57], it showed no HIV RNAase inhibitory activity [58], and also did not affect reverse transcriptase [59,60]. Low activity of friedelin (19) against para-influenza virus type3 was also observed in a study by Jiang et al. [61]. 


\subsection{Antiparasitic Activity}

Malaria kills more than two million people every year. Its etiological agent Plasmodium spp. frequently shows resistance to chloroquine and, for this reason, many scientists focused their research on finding new antimalarial remedies. Plant remedies would be a relatively convenient solution because of their accessibility [25]. An ethanolic extract from the bark of M. macrocarpa was tested for antimalarial and antileishmanial activities in ethnopharmacological studies carried out in Loreto, Peru [3]. It inhibited a chloroquine-susceptible strain of P. falciparum 3D7 at doses lower than $10 \mu \mathrm{g} / \mathrm{mL}$ (toxicity to human blood lymphocytes was proven at a dose of $48 \mu \mathrm{g} / \mathrm{mL}$ ) in vitro [3]. Recently, Vásquez-Ocmín et al. reported a study of 50 extracts from 46 medicinal plants used traditionally against protozoan diseases in Loreto (Peru) and an ethanolic extract from the bark of $M$. macrocarpa was one of the most active against $P$. falciparum 3D7 chloroquine-sensitive strain and against $P$. falciparum W2 chloroquine-resistant strain with $\mathrm{IC}_{50}=0.02 \mu \mathrm{g} / \mathrm{mL}$ for both strains [62]. Pristimerin (26), an active compound isolated from M. macrocarpa, is unfortunately toxic to human cells (HT-29) [3,63], but only at concentrations approximately 10 times higher than required to kill $P$. falciparum $\mathrm{K} 1$ and P. falciparum NF54 (IC 50190.4 and $270.9 \mathrm{ng} / \mathrm{mL}$, respectively) [63]. Other studies showed that 3-(E)-caffeoylbetulin (14) was inactive at $>50.0 \mu \mathrm{g} / \mathrm{mL}$ against $P$. falciparum $\mathrm{K} 1$ (multidrug-resistant strain) [64], and 3-(Z)-p-coumaroylbetulin (15) and 3-(E)-p-coumaroylbetulin (16) possess only low activity when tested on mice infected with $P$. berghei [65]. Friedelin (19) and canophyllol (20) showed some antiplasmodial activity when tested on the P. falciparum W2 strain (resistant to chloroquine) with $\mathrm{IC}_{50}$ values of 7.2 and $15.0 \mu \mathrm{M}$, respectively [66]; lower activity was shown in a study by Mitaine-Offer et al. [67], when the activities of friedelin (19) and canophyllol (20) were compared to chloroquine (on both chloroquine-resistant and chloroquine-sensitive $P$. falciparum strains). Although an ethanolic extract from the bark of M. macrocarpa was active against both P. falciparum 3D7 and P. falciparum W2, reports of any antimalarial-active compounds found in $M$. macrocarpa are relatively scarce. According to Cos et al. [29], research on potentially antimalarial-active compounds obtained from M. macrocarpa would benefit from the use of drug-resistant strains of Plasmodium.

Leishmaniasis is a serious disease that affects the developing world in particular. Three different forms of this disease are described - a cutaneous form (the most common), a mucocutaneous form (leading to partial or total destruction of mucous membranes), and a visceral form (the most serious form that can be lethal). Ethnopharmacological studies of $M$. macrocarpa describe its use to treat different wounds. Could the "wounds" reported by local people be the cutaneous form of leishmaniasis? The Leishmania major strain (the World Health Organization (WHO) referential strain) used in a brief antileishmanial-activity screening of an extract obtained from M. macrocarpa bark showed relatively strong inhibitory activity at doses lower than $10 \mu \mathrm{g} / \mathrm{mL}$. Unfortunately, no strains of local clinically isolated Leishmania parasites were available for this study, and only the promastigote form of Leishmania was used in the assay. The predictive value of the test is, therefore, limited, and more experiments should be carried out to confirm the effect [3]. A large study of the molecular docking of different substances, including a series of triterpenic compounds present in M. macrocarpa, identified the molecular protein targets of several Leishmania species [68]. Friedelin (19) preferentially targeted L. major tyrosyl-tRNA synthetase (docking energy $=-102.4 \mathrm{~kJ} / \mathrm{mol}$ ), whereas pristimerin (26) was strongly docked to L. major $\mathrm{N}$-myristoyltransferase (docking energy $=-112.9 \mathrm{~kJ} / \mathrm{mol}$ ), and lupeol (18) exerted the lowest-energy docked pose with L. major nucleoside hydrolase (docking energy $=-99.0 \mathrm{~kJ} / \mathrm{mol}$ ) [68]. Despite promising in silico results, friedelin (19) and epifriedelinol (29) showed no significant activity against L. donovani promastigotes $[69,70]$. Experiments with 3-caffeoylbetulin (14) showed it to be inactive against $L$. major as well [71]. Additionally, $1 \alpha, 6 \beta, 8 \beta, 15$-tetraacetoxy- $9 \alpha$-benzoyloxy- $4 \beta$-hydroxy- $\beta$-dihydroagarofuran (2), a dihydro- $\beta$-agarofuran sesquiterpene, is a promising antileishmanial substance isolated from M. macrocarpa. Alone, it possesses little direct cytotoxic activity against L. tropica, but it can also contribute to the effect of the currently used drug daunomycin by inhibiting the P-glycoprotein pump. This ATP-dependent transporting protein causes the efflux of daunomycin from cells [72]. Dihydro- $\beta$-agarofuran sesquiterpenes block the P-glycoprotein pump and more daunomycin stays 
inside the cells to kill Leishmania more effectively. Blockers with greater affinity were, however, already discovered [73].

An in silico molecular docking study was performed to investigate potential bioactive substances of antitrypanosomal plants. Although friedelin (19) was relatively weak docking ligands, it docked selectively with $T$. brucei uridine diphosphate (UDP)-galactose 4 '-epimerase [74]. On the other hand, friedelin (19) showed no antitrypanosomal activity in vitro $[70,75,76]$.

\subsection{Cytotoxic Activity}

Many studies of the cytotoxic activity of plant secondary metabolites were carried out, because of the urgent need for new remedies to treat cancer. M. macrocarpa was also examined as a potential source of cytotoxic substances. The direct cytotoxicity and mechanisms of effect of several compounds isolated from Maytenus were both analyzed. Pristimerin (26) inhibited DNA synthesis and triggered apoptosis in human HL-60 cells (promyelocytic leukemia cell line). It inhibited topoisomerase II, but it did not influence topoisomerase I [19]. Pristimerin (26) also showed activity against the following cell lines with $\mathrm{IC}_{50}$ values ranging from $0.55 \mu \mathrm{M}$ to $3.20 \mu \mathrm{M}$ : K-562 (chronic myelocytic leukemia), SF-295 (glyoblastoma), HCT-8 (colon carcinoma), and MDA/MB-435 (melanoma). However, except for MDA/MB-435, the dosage needed for the $\mathrm{IC}_{50}$ effect was greater than that for doxorubicin, which is taken as the standard reference drug. Pristimerin (26) was toxic to PBMC (peripheral blood mononuclear cells) in the same concentration range, suggesting that this compound is relatively unselective [19]. Another assay showed the cytotoxic potential of pristimerin (26) against $\mathrm{HL}-60\left(\mathrm{IC}_{50}=0.2 \mu \mathrm{M}\right)$ and MCF7 (breast adenocarcinoma) $\left(\mathrm{IC}_{50}=0.4 \mu \mathrm{M}\right)$ cell lines [77]. Recently, the NCI-60 cell line screen revealed that pristimerin (26) was active against UO-31 (renal carcinoma), T-47D (breast cancer), and A549 (non-small-cell lung cancer) human tumor cell lines with individual half maximal inhibition of cell proliferation $\left(\mathrm{GI}_{50}\right)$ values ranging from $0.12 \mu \mathrm{M}$ to $1.2 \mu \mathrm{M}$ [78]; therefore, pristimerin (26) would deserve further in vivo evaluation. Macrocarpine A (32), macrocarpine B (33), macrocarpine C (34), and macrocarpine D (35) were shown to be active against P-388D1 (mouse lymphoma), A-549 (human lung carcinoma), HT-29 (human colon carcinoma), and MEL-28 (human melanoma) cells with $\mathrm{IC}_{50}$ ranging between 0.4 and $5.2 \mu \mathrm{M}$ [24], whereas 28-hydroxyfriedelane-1,3-dione (22) was inactive against the same panel of cancer cell lines [16], but a positive control was missing in both studies. Compounds macrocarpine A-D (32-35) were isolated from a hexane fraction, which shows the relatively lipophilic characteristic that could impede their solubility in water and, therefore, the likelihood that they could be used as drugs [24]. An assay by Oramas-Royo et al. showed the activity of macrocarpine A (32) against HL-60 cells $\left(\mathrm{IC}_{50}=1.7 \mu \mathrm{M}\right)$ [77]. Vitideasin (25) was active against six solid tumor cell lines with $\mathrm{IC}_{50}$ ranging between 2.7 and $5.4 \mu \mathrm{M}$ [79]. However, only in vitro studies are presented so far, and in vivo studies are needed. Recently, a review showing the anti-cancer potential of celastrol (28) was published [80].

Derivatives of betulin are well known for cytotoxic properties. Several of them were isolated from M. macrocarpa (14-18). Furthermore, 3-(E)-caffeoylbetulin (14) and 3-(Z)-p-coumaroylbetulin (15) showed antitumor-promoting properties when tested in assays using the inhibition of soft agar colony induction by 12-O-tetradecanoylphorbol-13-acetate (TPA) in JB6 cells [81]. Similarly, 3-(E)-caffeoylbetulin (14) was reported as a potent cytotoxic agent against SK-OV-3 (ovary malignant ascites) and SK-MEL-2 (skin melanoma) human cancer cell lines with IC $_{50}$ values of 9.0 and $2.9 \mu \mathrm{M}$, respectively [82]. In another study, 3-(E)-caffeoylbetulin (14) exhibited moderate cytotoxic activity against KB (human oral epidermoid carcinoma) and NCI-H187 (human small-cell lung cancer) cell lines with $\mathrm{IC}_{50}$ values of 28.4 and $16.2 \mu \mathrm{M}$, respectively. Unfortunately, 3-(E)-caffeoylbetulin (14) was cytotoxic also against Vero cells $\left(\mathrm{IC}_{50}=8.9 \mu \mathrm{M}\right)$ [64]. On the other hand, a different study of 3-(E)-caffeoylbetulin (14) showed no significant cytotoxicity against $\mathrm{KB} / \mathrm{S}, \mathrm{KB} / \mathrm{VJ} 300$, and $\mathrm{KU}$ 19-20 cells [83]. Additionally, 3-(E)-p-coumaroylbetulin (16) showed activity against KB and HUVEC (human umbilical vein endothelial cells) cell lines [84]. Scutione (24) was tested for cytotoxic activity on HeLa $\left(\mathrm{IC}_{50}=4.9 \mu \mathrm{g} / \mathrm{mL}\right)$, Hep-2 $\left(\mathrm{IC}_{50}=5.6 \mu \mathrm{g} / \mathrm{mL}\right)$, and Vero $\left(\mathrm{IC}_{50}=7.2 \mu \mathrm{g} / \mathrm{mL}\right)$ cell lines and 
was not proven to be active compared with a positive control. This suggests dose-dependent activity against bacterial and mammalian cells and discriminating, non-specific toxicity [18]. Canophyllol (20) and friedelin (19) showed moderate activity against HL-60 cells with $\mathrm{IC}_{50}$ values of 17.1 and $48.5 \mu \mathrm{M}$, respectively [85]. In addition, friedelin (19) was used as a lead compound for the synthesis of several analogs with a dose-dependent ability to inhibit the catalytic activity of human topoisomerase II $\alpha$ [86]. The activity of friedelin (19) was found to be responsible for the anti-tumor effect of bamboo shavings used in traditional Chinese medicine [87]. Experiments using incubation with HeLa cells showed that the $\mathrm{IC}_{50}$ of friedelin (19) was $37 \mu \mathrm{M}$. Friedelane-type triterpenoids also showed some anti-tumor promoting activity. Friedelin (19) had an inhibitory effect on Epstein-Barr virus early antigen (EBV-EA) activation induced by TPA [88]. The application of selected triterpenes reduced inflammation in mouse ears induced by TPA and inhibited tumor genesis [89]. A search in literature for the bioactivity of lupeol (18) found a review showing it has anti-cancer potential [90].

Sesquiterpenes isolated from the leaves of $M$. macrocarpa, such as $6 \beta, 8 \beta, 15$-triacetoxy- $1 \alpha, 9 \alpha$-dibenzoyloxy-4 $\beta$-hydroxy- $\beta$-dihydroagarofuran $\quad$ (1) and $1 \alpha, 6 \beta, 8 \beta, 15$-tetraacetoxy-9 $\alpha$-(benzoyloxy)-4 $\beta$-hydroxy- $\beta$-dihydroagarofuran (2), were tested against P-388D1, A-549, HT-29, and MEL-28 cancer cell lines, but showed no significant cytotoxic activity [11].

\subsection{Anti-Inflammatory Activity}

The focus on anti-inflammatory activity was emphasized on the basis of usage of $M$. macrocarpa as a component of medicinal preparations for treating rheumatism, which was mentioned by almost all of the local people who were questioned during the ethnopharmacological research in the area of the natural distribution of the tree, irrespective of the geographic region or ethnic group [5,26].

Celastrol (28), a pentacyclic triterpene isolated from $M$. macrocarpa, was tested for anti-inflammatory activity. This compound is also connected to Chinese medicine, where it is isolated from the medicinal plant Tripterygium wilfordii Hook (Celastraceae) and used to treat rheumatoid arthritis and spondylitis [91]. Celastrol (28) was successful in many in vitro assays. It inhibited the release of interleukin (IL)- $1 \alpha$ and IL-1 $\beta$ from lipopolysaccharide-stimulated human PBMC cells, inhibited activation of nuclear factor kappa $B(N F-\kappa B)$ and caspase-1, and reduced the secretion of IL- $1 \beta$ and tumor necrosis factor (TNF)- $\alpha$ in a human THP-1 macrophage-like cell line, and already went through in vivo tests in rats as an effective blocker of IL-1 $\beta$ and TNF- $\alpha$, two cytokines connected with the development and progression of rheumatoid arthritis [91,92]. The question arises as to whether celastrol (28) is the only compound contained in M. macrocarpa that is responsible for anti-inflammatory activity. Some sources show that it may not be like that. In fact, 3-(E)-caffeoylbetulin (14) inhibited nitric oxide (NO) production $(9.3 \pm 3.2 \%$ of inhibition at $10 \mu \mathrm{M})$ and the formation of prostaglandin E2 (PGE2) $\left(\mathrm{IC}_{50}=10.8 \mu \mathrm{M}\right)$ [93], and 24-(E)-3-oxo-dammara-20,24-dien-26-ol (6) displayed moderate NO inhibitory activity $\left(\mathrm{IC}_{50}=22.36 \mu \mathrm{M}\right)$ [94] when tested in vitro on a system of RAW 264.7 cells stimulated by lipopolysaccharide (LPS). Lupeol (18) is a well-known substance with a multi-target anti-inflammatory potential as reported in reviews by Wal et al. [95] and Siddique and Saleem [96]. Oliveira-Junior et al. very recently demonstrated that lupeol (18) $(0.1 \mu \mathrm{M})$ exhibited anti-neuroinflammatory and neuroprotective activity in cerebellar cells [97]. Friedelin (19) can also possibly contribute to anti-inflammatory action [98], as shown by its lipoxygenase inhibitory activity [99] and several in vivo assays on mice [100]. On the other hand, cyclooxygenase was inhibited only slightly and lipoxygenase not at all in another study [101], and no inhibition of the platelet-activating factor (PAF)-stimulated release of $\beta$-glucuronidase from polymorphonuclear leukocytes was observed [102]. Friedelin (19) was identified as an active substance in a test of the inhibition of carrageenan-induced paw edema in rats [103], but an in vivo assay showed no activity of friedelin (19) and epifriedelinol (29) in the indomethacin-induced ulcer model in rats [104]. Friedelin (19) only slightly inhibited the production of NO in RAW 264.7 cells [105], and did not greatly inhibit the activity of nitric oxide synthase (NOS) in murine microglial cells [106], but it moderately inhibited the secretion of TNF- $\alpha$ 
in the latter cell line at the relatively low concentration of $100 \mathrm{nM}$ [107]. Little activity was observed when friedelin (19) was tested for the inhibition of human leukocyte elastase $(68 \%$ at a concentration of $25 \mu \mathrm{g} / \mathrm{mL}$ ), which was quite different from canophyllol (20), which showed much greater activity $\left(\mathrm{IC}_{50}\right.$ $=2.5 \mu \mathrm{M}$ ) [108]. Additionally, canophyllol (20) induced secretion of cytokines IL-6, IL-12, and TNF- $\alpha$ in PBMC cells [109], and triptotriterpenonic acid A (39) showed a weak inhibitory effect on IL-2 release $(27.0 \%$ inhibition at $10 \mu \mathrm{g} / \mathrm{mL})$ and interferon (IFN) $\gamma$ release $(66.7 \%$ inhibition at $10 \mu \mathrm{g} / \mathrm{mL})$ produced by lipopolysaccharide-stimulated human PBMC cells [21].

\subsection{Other}

Among other pharmacological activities described in the literature we found a positive effect of compounds from M. macrocarpa on impaired metabolic conditions, such as diabetes mellitus and obesity. Additionally, 3-(E)-caffeoylbetulin (14) showed weak $\alpha$-glucosidase inhibitory activity $(10.6 \%$ inhibition at $10 \mu \mathrm{g} / \mathrm{mL}$ ) [110], while $1 \alpha, 6 \beta, 8 \beta, 15$-tetraacetoxy-9 $\alpha$-(benzoyloxy)-4 $\beta$-hydroxy- $\beta$-dihydroagarofuran (2) displayed good $\alpha$-glucosidase inhibitory activity with $\mathrm{IC}_{50}$ values of $42.58 \mu \mathrm{M}$ [111]. Very recently, in vivo, in vitro, and in silico studies reported that lupeol (18) possesses antidiabetic effects through a peroxisome proliferator-activated receptor (PPAR) $\delta / \gamma$ dual agonist action [112], and canophyllol (20) stimulates the expression and translocation of glucose transporter 4 (GLUT4) in L6 myotubes in vitro $(30 \mu \mathrm{g} / \mathrm{mL})$, as well as in vivo in insulin-sensitive tissues of KK-Ay mice $(60 \mathrm{mg} / \mathrm{kg} / \mathrm{day})$ via activation of the AMP-activated protein kinase (AMPK) pathway [113].

On the other hand, 22-epi-maytenfolic acid (40) $\left(\mathrm{IC}_{50}=26 \mu \mathrm{M}\right)$ and maytenfolic acid (38) $\left(\mathrm{IC}_{50}=72 \mu \mathrm{M}\right)$ show inhibitory effects on rat lens aldose reductase, a key enzyme in the polyol pathway, where it catalyzes the reduction of glucose to sorbitol. Sorbitol does not readily diffuse across cell membranes, and the cellular accumulation of sorbitol was implicated in chronic complications of diabetes, such as cataracts [114].

Maytenfolic acid (38) was shown to induce lipolysis in rat epididymal fat-derived adipocytes at $100 \mathrm{mg} / \mathrm{L}(100 \mu \mathrm{g} / \mathrm{mL})$ [115]. The role of celastrol (28) in metabolic diseases was well reviewed by Lan et al. [116].

\subsection{Toxicity Studies}

Only one in vivo study using an ethanolic extract obtained from leaves of $M$. macrocarpa and intended to assess the safety of $M$. macrocarpa preparations was reported to date. A negative inotropic effect on the heart rate at a dose of $1500 \mathrm{mg} / \mathrm{kg}(1500 \mu \mathrm{g} / \mathrm{g})$ was observed. Furthermore, no significant changes in the rectal temperature of rats were recorded at doses of $500 \mathrm{mg} / \mathrm{kg}(500 \mu \mathrm{g} / \mathrm{g}), 1000 \mathrm{mg} / \mathrm{kg}$ $(1000 \mu \mathrm{g} / \mathrm{g})$, and $1500 \mathrm{mg} / \mathrm{kg}(1500 \mu \mathrm{g} / \mathrm{g})$ [117]. However, the extract was administrated to the rats intraperitoneally, which is not the usual method of application. Although we found many inaccuracies in this research, we can assume that this drug should be safe at the dosages traditionally used, but more research would be welcome and reassuring.

\section{Conclusions}

This review was prepared to summarize the ethnobotanical, phytochemical, and pharmacological information about M. macrocarpa, a tree in the Celastraceae family. It is distributed in tropical lowland rainforests, with some exceptions growing up to $2000 \mathrm{~m}$ above sea level. Only Kvist et al. mentioned the possibility of different constituent compounds occurring at different altitudes, but even these authors suggested this could be due to confusion involving the vernacular name chuchuhuasi, which may refer to one or both of the species, M. macrocarpa and M. amazonica, with the former found mostly in flood-plain forests and the latter in upland forests [3]. Examination of previous studies shows clearly that no differences between the content of compounds of lowland and highland trees were reported. Root and stem bark preparations of $M$. macrocarpa are widely used in Amazonian folk medicine to treat rheumatism and parasitic diseases. They are so popular that harvesting depleted the local M. macrocarpa trees close to villages [26]. Even so, the evidence 
needed to register it as an evidence-based drug is insufficient. The bioactive substances must be identified, and in vivo studies of their effects must be carried out. The best explored compounds of $M$. macrocarpa are tetracyclic and pentacyclic triterpenes, and the dihydro- $\beta$-agarofuran sesquiterpenes are also noteworthy. Unfortunately, most of the compounds that were discovered are relatively large lipophilic molecules, and their resultant limited solubility in water makes it harder to use them as drugs. Nevertheless, progress in pharmaceutical technology (e.g., nanocarriers, encapsulation) could improve their bioavailability and solve this problem.

Summarizing the biological tests, the vast majority of assays were carried out in vitro, and they are yet to bring forth any promising active compounds. Despite promising results of antibacterial activity of an ethanolic extract obtained from the root bark of $M$. macrocarpa, the antibacterial activity of isolated compounds is not very strong compared to currently used antibiotics. Only scutione (24) displayed strong antibacterial activity and no cytotoxicity; it would, therefore, be worth testing against methicillin-resistant S. aureus (MRSA) and vancomycin-resistant Enterococci (VRE) because of the urgent medical need for new antibiotics effective against these highly aggressive and resistant bacterial strains.

Pharmacokinetic and toxicological studies still do not exist, but it can be deduced from traditionally used doses of long-term local preparations that M. macrocarpa is relatively safe. More studies should be carried out to determine the full medicinal value of M. macrocarpa. No events of deaths or serious health problems resulting from the use of extracts obtained from $M$. macrocarpa were reported; therefore, we suppose it is safe to ingest.

Author Contributions: Conceptualization, M.M., L.K. and K.Š.; methodology, K.Š.; formal analysis, K.Š.; investigation, J.T., V.R., K.T., and P.K. (Petra Kaucká); data curation, K.Š., L.K.; writing-original draft preparation, K.Š., K.T., P.K. (Petra Kaucká); writing-review and editing, P.K. (Peter Kubatka), L.K.; visualization, K.Š.; supervision, K.Š.; project administration, K.Š., V.R.; funding acquisition, V.R.

Funding: This research was funded by IGA VFU Brno, grant number 307/2017/FAF.

Acknowledgments: Thanks to Frank Thomas Campbell for careful proofreading of the manuscript.

Conflicts of Interest: The authors declare no conflict of interest.

\section{References}

1. Liesner, R.L. Geography. In Catalogue of the vascular plants of Ecuador; Jørgensen, P.M., León-Yánez, S., Eds.; Missouri Botanical Garden Press: St. Louis, MO, USA, 1999; pp. 392-393.

2. USDA, ARS, National Genetic Resources Program. Germplasm Resources Information Network-(GRIN). National Germplasm Resources Laboratory, Beltsville, Maryland. Available online: https://npgsweb.ars-grin. gov/gringlobal/taxonomydetail.aspx?413469 (accessed on 31 May 2019).

3. Kvist, L.P.; Christensen, S.B.; Rasmussen, H.B.; Mejia, K.; Gonzalez, A. Identification and evaluation of Peruvian plants used to treat malaria and leishmaniasis. J. Ethnopharmacol. 2006, 106, 390-402. [CrossRef] [PubMed]

4. Mejia, K.; Rengifo, E. Plantas medicinales de uso popular en la Amazonia peruana; Agencia Española de Cooperación Internacional: Lima, Peru, 1995; ISBN 9972-614.00.5.

5. Sanz-Biset, J.; Campos-de-la-Cruz, J.; Epiquién-Rivera, M.A.; Cañigueral, S. A first survey on the medicinal plants of the Chazuta valley (Peruvian Amazon). J. Ethnopharmacol. 2009, 122, 333-362. [CrossRef] [PubMed]

6. Lombardi, J.A.; Groppo, M.; Biral, L. Celastraceae in Lista de Espécies da Flora do Brasil. Jardim Botânico do Rio de Janeiro. Available online: http://floradobrasil.jbrj.gov.br/jabot/floradobrasil/FB6746 (accessed on 31 May 2019).

7. The Plant List. Available online: http://www.theplantlist.org/ (accessed on 31 May 2019).

8. Alvarenga, N.; Ferro, E.A. Bioactive Triterpenes and Related Compounds from Celastraceae. Stud. Nat. Prod. Chem. 2005, 30, 635-702.

9. Biral, L.; Simmons, M.P.; Smidt, E.C.; Tembrock, L.R.; Bolson, M.; Archer, R.H.; Lombardi, J.A. Systematics of New World Maytenus (Celastraceae) and a New Delimitation of the Genus. Syst. Bot. 2017, 42, 1-14. [CrossRef] 
10. Niero, R.; de Andrade, S.F.; Cechinel Filho, V. A review of the ethnopharmacology, phytochemistry and pharmacology of plants of the Maytenus genus. Curr. Pharm. Des. 2011, 17, 1851-1871. [CrossRef] [PubMed]

11. Chávez, H.; Callo, N.; Estévez-Braun, A.; Ravelo, A.G.; González, A.G. Sesquiterpene polyol esters from the leaves of Maytenus macrocarpa. J. Nat. Prod. 1999, 62, 1576-1577. [CrossRef] [PubMed]

12. Torpocco, V.; Chávez, H.; Estévez-Braun, A.; Ravelo, A.G. New dammarane triterpenes from Maytenus macrocarpa. Chem. Pharm. Bull. 2007, 55, 812-814. [CrossRef] [PubMed]

13. Piacente, S.; Santos, L.C.D.; Mahmood, N.; Pizza, C. Triterpenes from Maytenus macrocarpa and Evaluation of Their Anti-HIV Activity. Nat. Prod. Comm. 2006, 1, 1934578X0600101201. [CrossRef]

14. Betancor, C.; Freire, R.; Gonzalez, A.G.; Salazar, J.A.; Pascard, C.; Prange, T. Three triterpenes and other terpenoids from Catha cassinoides. Phytochemistry 1980, 19, 1989-1993. [CrossRef]

15. Chávez, H.; Estévez-Braun, A.; Ravelo, Á.G.; González, A.G. First examples of dammarane triterpenes isolated from Celastraceae. Tetrahedron 1997, 53, 6465-6472. [CrossRef]

16. Chávez, H.; Estévez-Braun, A.; Ravelo, A.G.; González, A.G. Friedelane triterpenoids from Maytenus macrocarpa. J. Nat. Prod. 1998, 61, 82-85. [CrossRef]

17. Anjaneyulu, A.S.R.; Narayanarao, M. Elaeodendrol and elaeodendradiol, new nor-triterpenes from Elaeodendron glaucum. Phytochemistry 1980, 19, 1163-1169. [CrossRef]

18. González, A.G.; Alvarenga, N.L.; Ravelo, A.G.; Bazzocchi, I.L.; Ferro, E.A.; Navarro, A.G.; Moujir, L.M. Scutione, a new bioactive norquinonemethide triterpene from Maytenus scutioides (Celastraceae). Bioorg. Med. Chem. 1996, 4, 815-820. [CrossRef]

19. Da Costa, P.M.; Ferreira, P.M.P.; da Silva Bolzani, V.; Furlan, M.; de Freitas Formenton Macedo Dos Santos, V.A.; Corsino, J.; de Moraes, M.O.; Costa-Lotufo, L.V.; Montenegro, R.C.; Pessoa, C. Antiproliferative activity of pristimerin isolated from Maytenus ilicifolia (Celastraceae) in human HL-60 cells. Toxicol In Vitro 2008, 22, 854-863. [CrossRef]

20. Itoh, T.; Tamura, T.; Matsumoto, T. Triterpene alcohols in the seeds of solanaceae. Phytochemistry 1977, 16, 1723-1726. [CrossRef]

21. Duan, H.; Takaishi, Y.; Momota, H.; Ohmoto, Y.; Taki, T.; Jia, Y.; Li, D. Triterpenoids from Tripterygium wilfordii. Phytochemistry 2000, 53, 805-810. [CrossRef]

22. Itokawa, H.; Shirota, O.; Ikuta, H.; Morita, H.; Takeya, K.; Iitaka, Y. Triterpenes fromMaytenus ilicifolia. Phytochemistry 1991, 30, 3713-3716. [CrossRef]

23. Liang, G.-Y.; Gray, A.L.; Waterman, P.G. Tirucallane and oleanane triterpenes from the resin of Aucoumea klaineana. Phytochemistry 1988, 27, 2283-2286. [CrossRef]

24. Chávez, H.; Rodríguez, G.; Estévez-Braun, A.; Ravelo, A.G.; Estévez-Reyes, R.; González, A.G.; Fdez-Puente, J.L.; García-Grávalos, D. Macrocarpins A-D, new cytotoxic nor-triterpenes from Maytenus macrocarpa. Bioorg. Med. Chem. Lett. 2000, 10, 759-762. [CrossRef]

25. Ruiz, L.; Ruiz, L.; Maco, M.; Cobos, M.; Gutierrez-Choquevilca, A.-L.; Roumy, V. Plants used by native Amazonian groups from the Nanay River (Peru) for the treatment of malaria. J. Ethnopharmacol. 2011, 133, 917-921. [CrossRef]

26. Kvist, L.P.; Andersen, M.K.; Stagegaard, J.; Hesselsøe, M.; Llapapasca, C. Extraction from woody forest plants in flood plain communities in Amazonian Peru: Use, choice, evaluation and conservation status of resources. Forest Ecol. Manag. 2001, 150, 147-174. [CrossRef]

27. Graham, J.G.; Quinn, M.L.; Fabricant, D.S.; Farnsworth, N.R. Plants used against cancer - an extension of the work of Jonathan Hartwell. J. Ethnopharmacol. 2000, 73, 347-377. [CrossRef]

28. Sanz-Biset, J.; Cañigueral, S. Plant use in the medicinal practices known as "strict diets" in Chazuta valley (Peruvian Amazon). J. Ethnopharmacol. 2011, 137, 271-288. [CrossRef] [PubMed]

29. Cos, P.; Vlietinck, A.J.; Berghe, D.V.; Maes, L. Anti-infective potential of natural products: How to develop a stronger in vitro "proof-of-concept". J. Ethnopharmacol. 2006, 106, 290-302. [CrossRef] [PubMed]

30. Kloucek, P.; Svobodova, B.; Polesny, Z.; Langrova, I.; Smrcek, S.; Kokoska, L. Antimicrobial activity of some medicinal barks used in Peruvian Amazon. J. Ethnopharmacol. 2007, 111, 427-429. [CrossRef] [PubMed]

31. Kloucek, P.; Polesny, Z.; Svobodova, B.; Vlkova, E.; Kokoska, L. Antibacterial screening of some Peruvian medicinal plants used in Callería District. J. Ethnopharmacol. 2005, 99, 309-312. [CrossRef] [PubMed]

32. Mutai, C.; Bii, C.; Vagias, C.; Abatis, D.; Roussis, V. Antimicrobial activity of Acacia mellifera extracts and lupane triterpenes. J. Ethnopharmacol. 2009, 123, 143-148. [CrossRef] [PubMed] 
33. Orabi, K.Y.; Al-Qasoumi, S.I.; El-Olemy, M.M.; Mossa, J.S.; Muhammad, I. Dihydroagarofuran alkaloid and triterpenes from Maytenus heterophylla and Maytenus arbutifolia. Phytochemistry 2001, 58, 475-480. [CrossRef]

34. Christopher, R.; Nyandoro, S.S.; Chacha, M.; de Koning, C.B. A new cinnamoylglycoflavonoid, antimycobacterial and antioxidant constituents from Heritiera littoralis leaf extracts. Nat. Prod. Res. 2014, 28, 351-358. [CrossRef] [PubMed]

35. Higuchi, C.T.; Pavan, F.R.; Leite, C.Q.F.; Sannomiya, M.; Vilegas, W.; de Andrade Leite, S.R.; Sacramento, L.V.S.; Sato, D.N. Triterpenes and antitubercular activity of Byrsonima crassa. Química Nova 2008, 31, 1719-1721. [CrossRef]

36. Lannang, A.M.; Noudou, B.S.; Sewald, N. Ovalifolone A and B: New friedelane derivatives from Garcinia ovalifolia. Phytochem. Lett. 2013, 6, 157-161. [CrossRef]

37. Mokoka, T.A.; McGaw, L.J.; Mdee, L.K.; Bagla, V.P.; Iwalewa, E.O.; Eloff, J.N. Antimicrobial activity and cytotoxicity of triterpenes isolated from leaves of Maytenus undata (Celastraceae). BMC Complement Altern. Med. 2013, 13, 111. [CrossRef] [PubMed]

38. Ribeiro, P.R.; Ferraz, C.G.; Guedes, M.L.S.; Martins, D.; Cruz, F.G. A new biphenyl and antimicrobial activity of extracts and compounds from Clusia burlemarxii. Fitoterapia 2011, 82, 1237-1240. [CrossRef] [PubMed]

39. Tamokou, J.D.D.; Tala, M.F.; Wabo, H.K.; Kuiate, J.R.; Tane, P. Antimicrobial activities of methanol extract and compounds from stem bark of Vismia rubescens. J. Ethnopharmacol. 2009, 124, 571-575. [CrossRef] [PubMed]

40. Liu, C.-M.; Wang, H.-X.; Wei, S.-L.; Gao, K. Oleanane-Type Triterpenes from the Flowers and Roots of Saussurea muliensis. J. Nat. Prod. 2008, 71, 789-792. [CrossRef]

41. Madureira, A.M.; Ascenso, J.R.; Valdeira, L.; Duarte, A.; Frade, J.P.; Freitas, G.; Ferreira, M.J.U. Evaluation of the antiviral and antimicrobial activities of triterpenes isolated from Euphorbia segetalis. Nat. Prod. Res. 2003, 17, 375-380. [CrossRef]

42. Viswanathan, M.B.G.; Jeya Ananthi, J.D.; Sathish Kumar, P. Antimicrobial activity of bioactive compounds and leaf extracts in Jatropha tanjorensis. Fitoterapia 2012, 83, 1153-1159. [CrossRef]

43. Ragasa, C.Y.; Espineli, D.L.; Mandia, E.H.; Raga, D.D.; Don, M.-J.; Shen, C.-C. A New Triterpene from Atalantia retusa Merr. Z. Naturforsch. B 2014, 67, 426-432. [CrossRef]

44. Jain, S.C.; Singh, B.; Jain, R. Antimicrobial activity of triterpenoids from Heliotropium ellipticum. Fitoterapia 2001, 72, 666-668. [CrossRef]

45. Singh, B.; Dubey, M.M. Estimation of triterpenoids from Heliotropium marifolium Koen. ex Retz. in vivo and in vitro. I. Antimicrobial screening. Phytother. Res. 2001, 15, 231-234. [CrossRef]

46. Kuete, V.; Komguem, J.; Beng, V.P.; Meli, A.L.; Tangmouo, J.G.; Etoa, F.-X.; Lontsi, D. Antimicrobial components of the methanolic extract from the stem bark of Garcinia smeathmannii Oliver (Clusiaceae). $S$. Afr. J. Bot. 2007, 73, 347-354. [CrossRef]

47. Kuete, V.; Nguemeving, J.R.; Beng, V.P.; Azebaze, A.G.B.; Etoa, F.-X.; Meyer, M.; Bodo, B.; Nkengfack, A.E. Antimicrobial activity of the methanolic extracts and compounds from Vismia laurentii De Wild (Guttiferae). J. Ethnopharmacol. 2007, 109, 372-379. [CrossRef] [PubMed]

48. Shaiq Ali, M.; Mahmud, S.; Perveen, S.; Rizwani, G.H.; Ahmad, V.U. Screening for the Antimicrobial Properties of the Leaves of Calophyllum inophyllum Linn. (Guttiferae). J. Chem. Soc. Pak. 1999, 21, 174-178.

49. Chiozem, D.D.; Trinh-Van-Dufat, H.; Wansi, J.D.; Mbazoa Djama, C.; Fannang, V.S.; Seguin, E.; Tillequin, F.; Wandji, J. New friedelane triterpenoids with antimicrobial activity from the stems of Drypetes paxii. Chem. Pharm. Bull. 2009, 57, 1119-1122. [CrossRef] [PubMed]

50. Gerrish, D.; Kim, I.C.; Kumar, D.V.; Austin, H.; Garrus, J.E.; Baichwal, V.; Saunders, M.; McKinnon, R.S.; Anderson, M.B.; Carlson, R.; et al. Triterpene based compounds with potent anti-maturation activity against HIV-1. Bioorg. Med. Chem. Lett. 2008, 18, 6377-6380. [CrossRef] [PubMed]

51. Mukhtar, M.; Arshad, M.; Ahmad, M.; Pomerantz, R.J.; Wigdahl, B.; Parveen, Z. Antiviral potentials of medicinal plants. Virus Res. 2008, 131, 111-120. [CrossRef]

52. Aiken, C.; Chen, C.H. Betulinic acid derivatives as HIV-1 antivirals. Trends Mol. Med. 2005, 11, 31-36. [CrossRef]

53. Ng, T.B.; Huang, B.; Fong, W.P.; Yeung, H.W. Anti-human immunodeficiency virus (anti-HIV) natural products with special emphasis on HIV reverse transcriptase inhibitors. Life Sci. 1997, 61, 933-949. [CrossRef]

54. Wu, P.-L.; Lin, F.-W.; Wu, T.-S.; Kuoh, C.-S.; Lee, K.-H.; Lee, S.-J. Cytotoxic and anti-HIV principles from the rhizomes of Begonia nantoensis. Chem. Pharm. Bull. 2004, 52, 345-349. [CrossRef] 
55. Callies, O.; Bedoya, L.M.; Beltrán, M.; Muñoz, A.; Calderón, P.O.; Osorio, A.A.; Jiménez, I.A.; Alcamí, J.; Bazzocchi, I.L. Isolation, Structural Modification, and HIV Inhibition of Pentacyclic Lupane-Type Triterpenoids from Cassine xylocarpa and Maytenus cuzcoina. J. Nat. Prod. 2015, 78, 1045-1055. [CrossRef] [PubMed]

56. Kuo, Y.H.; Kuo, L.M. Antitumour and anti-AIDS triterpenes from Celastrus hindsii. Phytochemistry 1997, 44, 1275-1281.

57. Ren, H.-C.; Qin, R.-D.; Wang, Q.; Cheng, W.; Zhang, Q.-Y.; Liang, H. A new triterpenoid and a new glycoside from Pilea cavaleriei. J. Asian Nat. Prod. Res. 2012, 14, 1032-1038. [CrossRef] [PubMed]

58. Dat, N.T.; Bae, K.; Wamiru, A.; McMahon, J.B.; Le Grice, S.F.J.; Bona, M.; Beutler, J.A.; Kim, Y.H. A dimeric lactone from Ardisia japonica with inhibitory activity for HIV-1 and HIV-2 ribonuclease H. J. Nat. Prod. 2007, 70, 839-841. [CrossRef] [PubMed]

59. Reutrakul, V.; Chanakul, W.; Pohmakotr, M.; Jaipetch, T.; Yoosook, C.; Kasisit, J.; Napaswat, C.; Santisuk, T.; Prabpai, S.; Kongsaeree, P.; et al. Anti-HIV-1 constituents from leaves and twigs of Cratoxylum arborescens. Planta Med. 2006, 72, 1433-1435. [CrossRef] [PubMed]

60. Huerta-Reyes, M.; Basualdo, M.D.C.; Abe, F.; Jimenez-Estrada, M.; Soler, C.; Reyes-Chilpa, R. HIV-1 inhibitory compounds from Calophyllum brasiliense leaves. Biol. Pharm. Bull. 2004, 27, 1471-1475. [CrossRef]

61. Jiang, R.-W.; Ma, S.-C.; He, Z.-D.; Huang, X.-S.; But, P.P.-H.; Wang, H.; Chan, S.-P.; Ooi, V.E.-C.; Xu, H.-X.; Mak, T.C.W. Molecular structures and antiviral activities of naturally occurring and modified cassane furanoditerpenoids and friedelane triterpenoids from Caesalpinia minax. Bioorg. Med. Chem. 2002, 10, 2161-2170. [CrossRef]

62. Vásquez-Ocmín, P.; Cojean, S.; Rengifo, E.; Suyyagh-Albouz, S.; Amasifuen Guerra, C.A.; Pomel, S.; Cabanillas, B.; Mejía, K.; Loiseau, P.M.; Figadère, B.; et al. Antiprotozoal activity of medicinal plants used by Iquitos-Nauta road communities in Loreto (Peru). J. Ethnopharmacol. 2018, 210, 372-385. [CrossRef]

63. Figueiredo, J.N.; Räz, B.; Séquin, U. Novel quinone methides from Salacia kraussii with in vitro antimalarial activity. J. Nat. Prod. 1998, 61, 718-723. [CrossRef]

64. Lomchid, P.; Nasomjai, P.; Kanokmedhakul, S.; Boonmak, J.; Youngme, S.; Kanokmedhakul, K. Bioactive Lupane and Hopane Triterpenes from Lepisanthes senegalensis. Planta Med. 2017, 83, 334-340. [CrossRef]

65. Mutai, C.; Rukunga, G.; Vagias, C.; Roussis, V. In vivo screening of antimalarial activity of Acacia mellifera (Benth) (Leguminosae) on Plasmodium berghei in mice. Afr J Tradit Complement Altern. Med. 2007, 5, 46-50. [CrossRef]

66. Ngouamegne, E.T.; Fongang, R.S.; Ngouela, S.; Boyom, F.F.; Rohmer, M.; Tsamo, E.; Gut, J.; Rosenthal, P.J. Endodesmiadiol, a friedelane triterpenoid, and other antiplasmodial compounds from Endodesmia calophylloides. Chem. Pharm. Bull. 2008, 56, 374-377. [CrossRef] [PubMed]

67. Mitaine-Offer, A.-C.; Sauvain, M.; Deharo, E.; Muñoz, V.; Zèches-Hanrot, M. A new diterpene from Tanaecium jaroba. Planta Med. 2002, 68, 568-569. [CrossRef] [PubMed]

68. Ogungbe, I.V.; Setzer, W.N. In-silico Leishmania target selectivity of antiparasitic terpenoids. Molecules 2013, 18, 7761-7847. [CrossRef] [PubMed]

69. Torres-Santos, E.C.; Lopes, D.; Oliveira, R.R.; Carauta, J.P.P.; Falcao, C.A.B.; Kaplan, M. a. C.; Rossi-Bergmann, B. Antileishmanial activity of isolated triterpenoids from Pourouma guianensis. Phytomedicine 2004, 11, 114-120. [CrossRef] [PubMed]

70. Camacho, M.R.; Mata, R.; Castaneda, P.; Kirby, G.C.; Warhurst, D.C.; Croft, S.L.; Phillipson, J.D. Bioactive compounds from Celaenodendron mexicanum. Planta Med. 2000, 66, 463-468. [CrossRef]

71. Takahashi, M.; Fuchino, H.; Sekita, S.; Satake, M. In vitro leishmanicidal activity of some scarce natural products. Phytother. Res. 2004, 18, 573-578. [CrossRef] [PubMed]

72. Cortés-Selva, F.; Jiménez, I.A.; Munoz-Martínez, F.; Campillo, M.; Bazzocchi, I.L.; Pardo, L.; Ravelo, A.G.; Castanys, S.; Gamarro, F. Dihydro-beta-agarofuran sesquiterpenes: A new class of reversal agents of the multidrug resistance phenotype mediated by P-glycoprotein in the protozoan parasite Leishmania. Curr. Pharm. Des. 2005, 11, 3125-3139. [CrossRef]

73. Pérez-Victoria, J.M.; Tincusi, B.M.; Jiménez, I.A.; Bazzocchi, I.L.; Gupta, M.P.; Castanys, S.; Gamarro, F.; Ravelo, A.G. New natural sesquiterpenes as modulators of daunomycin resistance in a multidrug-resistant Leishmania tropica line. J. Med. Chem. 1999, 42, 4388-4393. [CrossRef]

74. Setzer, W.N.; Ogungbe, I.V. In-silico Investigation of Antitrypanosomal Phytochemicals from Nigerian Medicinal Plants. PLOS Negl. Trop. Dis. 2012, 6, e1727. [CrossRef] 
75. Abe, F.; Nagafuji, S.; Okabe, H.; Akahane, H.; Estrada-Muñiz, E.; Huerta-Reyes, M.; Reyes-Chilpa, R. Trypanocidal constituents in plants 3. Leaves of Garcinia intermedia and heartwood of Calophyllum brasiliense. Biol. Pharm. Bull. 2004, 27, 141-143. [CrossRef]

76. Biavatti, M.W.; Vieira, P.C.; da Silva, M.F.G.F.; Fernandes, J.B.; Albuquerque, S.; Magalhães, C.M.; Pagnocca, F.C. Chemistry and bioactivity of Raulinoa echinata Cowan, an endemic Brazilian Rutaceae species. Phytomedicine 2001, 8, 121-124. [CrossRef] [PubMed]

77. Oramas-Royo, S.M.; Chávez, H.; Martín-Rodíguez, P.; Fernández-Pérez, L.; Ravelo, A.G.; Estévez-Braun, A. Cytotoxic triterpenoids from Maytenus retusa. J. Nat. Prod. 2010, 73, 2029-2034. [CrossRef] [PubMed]

78. Espindola, L.S.; Dusi, R.G.; Demarque, D.P.; Braz-Filho, R.; Yan, P.; Bokesch, H.R.; Gustafson, K.R.; Beutler, J.A. Cytotoxic Triterpenes from Salacia crassifolia and Metabolite Profiling of Celastraceae Species. Molecules 2018, 23. [CrossRef] [PubMed]

79. de Almeida, M.T.R.; Ríos-Luci, C.; Padrón, J.M.; Palermo, J.A. Antiproliferative terpenoids and alkaloids from the roots of Maytenus vitis-idaea and Maytenus spinosa. Phytochemistry 2010, 71, 1741-1748. [CrossRef] [PubMed]

80. Chen, S.-R.; Dai, Y.; Zhao, J.; Lin, L.; Wang, Y.; Wang, Y. A Mechanistic Overview of Triptolide and Celastrol, Natural Products from Tripterygium wilfordii Hook F. Front Pharmacol. 2018, 9, 104. [CrossRef]

81. Gao, H.; Wu, L.; Kuroyanagi, M.; Harada, K.; Kawahara, N.; Nakane, T.; Umehara, K.; Hirasawa, A.; Nakamura, Y. Antitumor-promoting constituents from Chaenomeles sinensis KOEHNE and their activities in JB6 mouse epidermal cells. Chem. Pharm. Bull. 2003, 51, 1318-1321. [CrossRef]

82. Kim, C.S.; Subedi, L.; Oh, J.; Kim, S.Y.; Choi, S.U.; Lee, K.R. Bioactive Triterpenoids from the Twigs of Chaenomeles sinensis. J. Nat. Prod. 2017, 80, 1134-1140. [CrossRef]

83. Ohsaki, A.; Imai, Y.; Naruse, M.; Ayabe, S.-I.; Komiyama, K.; Takashima, J. Four new triterpenoids from Maytenus ilicifolia. J. Nat. Prod. 2004, 67, 469-471. [CrossRef]

84. Hwang, B.Y.; Chai, H.-B.; Kardono, L.B.S.; Riswan, S.; Farnsworth, N.R.; Cordell, G.A.; Pezzuto, J.M.; Kinghorn, A.D. Cytotoxic triterpenes from the twigs of Celtis philippinensis. Phytochemistry 2003, 62, 197-201. [CrossRef]

85. Thao, N.T.P.; Hung, T.M.; Lee, M.K.; Kim, J.C.; Min, B.S.; Bae, K. Triterpenoids from Camellia japonica and their cytotoxic activity. Chem. Pharm. Bull. 2010, 58, 121-124. [CrossRef]

86. Mandal, A.; Ghosh, S.; Bothra, A.K.; Nanda, A.K.; Ghosh, P. Synthesis of friedelan triterpenoid analogs with DNA topoisomerase II $\alpha$ inhibitory activity and their molecular docking studies. Eur. J. Med. Chem. 2012, 54, 137-143. [CrossRef] [PubMed]

87. Lu, B.; Liu, L.; Zhen, X.; Wu, X.; Zhang, Y. Anti-tumor activity of triterpenoid-rich extract from bamboo shavings (Caulis bamfusae in Taeniam). Afr. J. Biotechnol. 2010, 9, 6430-6436.

88. Tanaka, R.; Nakata, T.; Yamaguchi, C.; Wada, S.-I.; Yamada, T.; Tokuda, H. Potential anti-tumor-promoting activity of 3alpha-hydroxy-D:A-friedooleanan-2-one from the stem bark of Mallotus philippensis. Planta Med. 2008, 74, 413-416. [CrossRef]

89. Yasukawa, K.; Takido, M.; Matsumoto, T.; Takeuchi, M.; Nakagawa, S. Sterol and triterpene derivatives from plants inhibit the effects of a tumor promoter, and sitosterol and betulinic acid inhibit tumor formation in mouse skin two-stage carcinogenesis. Oncology 1991, 48, 72-76. [CrossRef] [PubMed]

90. Saleem, M. Lupeol, a novel anti-inflammatory and anti-cancer dietary triterpene. Cancer Lett. 2009, 285, 109-115. [CrossRef]

91. Takaishi, Y.; Wariishi, N.; Tateishi, H.; Kawazoe, K.; Nakano, K.; Ono, Y.; Tokuda, H.; Nishino, H.; Iwashima, A. Triterpenoid inhibitors of interleukin-1 secretion and tumour-promotion from Tripterygium wilfordii var. regelii. Phytochemistry 1997, 45, 969-974. [CrossRef]

92. Cascão, R.; Vidal, B.; Raquel, H.; Neves-Costa, A.; Figueiredo, N.; Gupta, V.; Fonseca, J.E.; Moita, L.F. Effective treatment of rat adjuvant-induced arthritis by celastrol. Autoimmun. Rev. 2012, 11, 856-862. [CrossRef]

93. Reyes, C.P.; Núñez, M.J.; Jiménez, I.A.; Busserolles, J.; Alcaraz, M.J.; Bazzocchi, I.L. Activity of lupane triterpenoids from Maytenus species as inhibitors of nitric oxide and prostaglandin E2. Bioorg. Med. Chem. 2006, 14, 1573-1579. [CrossRef]

94. Huang, S.-S.; Jian, K.-L.; Li, R.-J.; Kong, L.-Y.; Yang, M.-H. Phytosteroids and triterpenoids with potent cytotoxicities from the leaves of Chisocheton cumingianus. RSC Adv. 2016, 6, 6320-6328. [CrossRef]

95. Wal, P.; Wal, A.; Sharma, G.; Rai, A. Biological Activities of Lupeol. Systematic Reviews in Pharmacy $2011,2$. [CrossRef] 
96. Siddique, H.R.; Saleem, M. Beneficial health effects of lupeol triterpene: A review of preclinical studies. Life Sci. 2011, 88, 285-293. [CrossRef]

97. Oliveira-Junior, M.S.; Pereira, E.P.; de Amorim, V.C.M.; Reis, L.T.C.; do Nascimento, R.P.; da Silva, V.D.A.; Costa, S.L. Lupeol inhibits LPS-induced neuroinflammation in cerebellar cultures and induces neuroprotection associated to the modulation of astrocyte response and expression of neurotrophic and inflammatory factors. Int. Immunopharmacol. 2019, 70, 302-312. [CrossRef] [PubMed]

98. Ignoato, M.C.; Fabrão, R.M.; Schuquel, I.T.A.; Botelho, M.F.P.; Bannwart, G.; Pomini, A.M.; Arruda, L.L.M.; Bersani-Amado, C.A.; Santin, S.M.O. Chemical constituents of Machaerium hirtum Vell. (Fabaceae) leaves and branches and its anti-inflammatory activity evaluation. Nat. Prod. Res. 2013, 27, 1556-1561. [CrossRef] [PubMed]

99. Kumari, R.; Meyyappan, A.; Selvamani, P.; Mukherjee, J.; Jaisankar, P. Lipoxygenase inhibitory activity of crude bark extracts and isolated compounds from Commiphora berryi. J. Ethnopharmacol. 2011, 138, $256-259$. [CrossRef] [PubMed]

100. Antonisamy, P.; Duraipandiyan, V.; Ignacimuthu, S. Anti-inflammatory, analgesic and antipyretic effects of friedelin isolated from Azima tetracantha Lam. in mouse and rat models. J. Pharm. Pharmacol. 2011, 63, 1070-1077. [CrossRef] [PubMed]

101. Ming Shan ZHENG, J.H.Y.; Son, J.-K. Anti-Inflammatory Activity of Constituents Isolated from Ulmus davidiana var. japonica. Biomol. Ther. 2010, 18, 321-328. [CrossRef]

102. Fan, X.; Zi, J.; Zhu, C.; Xu, W.; Cheng, W.; Yang, S.; Guo, Y.; Shi, J. Chemical Constituents of Heteroplexis micocephala. J. Nat. Prod. 2009, 72, 1184-1190. [CrossRef] [PubMed]

103. Shimizu, M.; Tomoo, T. Anti-inflammatory constituents of topically applied crude drugs. V. Constituents and anti-inflammatory effect of Aoki, Aucuba japonica Thunb. Biol. Pharm. Bull. 1994, 17, 665-667. [CrossRef] [PubMed]

104. Queiroga, C.L.; Silva, G.F.; Dias, P.C.; Possenti, A.; de Carvalho, J.E. Evaluation of the antiulcerogenic activity of friedelan-3beta-ol and friedelin isolated from Maytenus ilicifolia (Celastraceae). J. Ethnopharmacol. 2000, 72, 465-468. [CrossRef]

105. Tewtrakul, S.; Tansakul, P.; Daengrot, C.; Ponglimanont, C.; Karalai, C. Anti-inflammatory principles from Heritiera littoralis bark. Phytomedicine 2010, 17, 851-855. [CrossRef]

106. Tsao, C.-C.; Shen, Y.-C.; Su, C.-R.; Li, C.-Y.; Liou, M.-J.; Dung, N.-X.; Wu, T.-S. New diterpenoids and the bioactivity of Erythrophleum fordii. Bioorg. Med. Chem. 2008, 16, 9867-9870. [CrossRef] [PubMed]

107. Ding, Y.; Liang, C.; Kim, J.H.; Lee, Y.-M.; Hyun, J.-H.; Kang, H.-K.; Kim, J.-A.; Min, B.S.; Kim, Y.H. Triterpene compounds isolated from Acer mandshuricum and their anti-inflammatory activity. Bioorg. Med. Chem. Lett. 2010, 20, 1528-1531. [CrossRef] [PubMed]

108. Mitaine-Offer, A.-C.; Hornebeck, W.; Sauvain, M.; Zèches-Hanrot, M. Triterpenes and phytosterols as human leucocyte elastase inhibitors. Planta Med. 2002, 68, 930-932. [CrossRef] [PubMed]

109. Nakagawa, H.; Takaishi, Y.; Fujimoto, Y.; Duque, C.; Garzon, C.; Sato, M.; Okamoto, M.; Oshikawa, T.; Ahmed, S.U. Chemical Constituents from the Colombian Medicinal Plant Maytenus laevis. J. Nat. Prod. 2004, 67, 1919-1924. [CrossRef] [PubMed]

110. Lai, Y.-C.; Chen, C.-K.; Tsai, S.-F.; Lee, S.-S. Triterpenes as $\alpha$-glucosidase inhibitors from Fagus hayatae. Phytochemistry 2012, 74, 206-211. [CrossRef] [PubMed]

111. Sasikumar, P.; Sharathna, P.; Prabha, B.; Sunil, S.; Anil Kumar, N.; Sivan, V.V.; Sherin, D.R.; Suresh, E.; Manojkumar, T.K.; Radhakrishnan, K.V. Dihydro- $\beta$-agarofuran sesquiterpenoids from the seeds of Celastrus paniculatus Willd. and their $\alpha$-glucosidase inhibitory activity. Phytochem. Lett. 2018, 26, 1-8.

112. Giacoman-Martínez, A.; Alarcón-Aguilar, F.J.; Zamilpa, A.; Hidalgo-Figueroa, S.; Navarrete-Vázquez, G.; García-Macedo, R.; Román-Ramos, R.; Almanza-Pérez, J.C. Triterpenoids from Hibiscus sabdariffa L. with

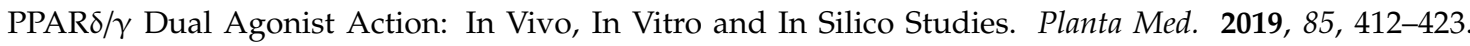
[CrossRef] [PubMed]

113. Lv, Y.; Ming, Q.; Hao, J.; Huang, Y.; Chen, H.; Wang, Q.; Yang, X.; Zhao, P. Anti-diabetic activity of canophyllol from Cratoxylum cochinchinense (Lour.) Blume in type 2 diabetic mice by activation of AMP-activated kinase and regulation of PPAR $\gamma$. Food Funct. 2019, 10, 964-977. [CrossRef] [PubMed]

114. Morikawa, T.; Kishi, A.; Pongpiriyadacha, Y.; Matsuda, H.; Yoshikawa, M. Structures of new friedelane-type triterpenes and eudesmane-type sesquiterpene and aldose reductase inhibitors from Salacia chinensis. J. Nat. Prod. 2003, 66, 1191-1196. [CrossRef] 
115. Yoshikawa, M.; Shimoda, H.; Nishida, N.; Takada, M.; Matsuda, H. Salacia reticulata and its polyphenolic constituents with lipase inhibitory and lipolytic activities have mild antiobesity effects in rats. J. Nutr. 2002, 132, 1819-1824. [CrossRef]

116. Lan, G.; Zhang, J.; Ye, W.; Yang, F.; Li, A.; He, W.; Zhang, W.-D. Celastrol as a tool for the study of the biological events of metabolic diseases. Sci. China Chem. 2019, 62, 409-416. [CrossRef]

117. Huaccho Rojas, J.J.; Cavero Aguilar, E.S.; Quezada Rojas, M.A.; Lara Paredes, A.M.; Lluen Escobar, S.E.; Paragulla Bocángel, A.A.; Rojas Villacorta, F.J.; Loja Herrera, B.; Alvarado Yarasca, Á.; Mujica Calderón, J.; et al. Efectos sobre la temperatura, frecuencia respiratoria, frecuencia cardiaca y electrocardiograma de Maytenus macrocarpa (Ruiz \& Pav.) Briq. (chuchuhuasi). [Effects of Maytenus macrocarpa (Ruiz \& Pav.) Briq. (chuchuhuasi) in temperature, respiratory rate, heart rate, and electrocardiogram]. Rev. Cuba. de Plantas Med. 2012, 17, 233-243.

(C) 2019 by the authors. Licensee MDPI, Basel, Switzerland. This article is an open access article distributed under the terms and conditions of the Creative Commons Attribution (CC BY) license (http://creativecommons.org/licenses/by/4.0/). 